\title{
INFESTASI Argulus PADA IKAN MAS (Cyprinus carpio, L.) DI DASAR KOLAM TANAH DAN BETON, KECAMATAN MUNTILAN DAN MUNGKID, KABUPATEN MAGELANG
}

\author{
Infestations Argulus In Carp (Cyprinus carpio, L.) At The Pond Land Base And \\ Concrete Base, Muntilan And Mungkid Sub-Districts, Magelang District
}

\author{
Arika Juniarsih $^{1 *}$, Gunanti Mahasri ${ }^{2}$ dan Kismiyati ${ }^{2}$ \\ ${ }^{1}$ Program Studi Budidaya Perairan, Fakultas Perikanan dan Kelautan, Universitas Airlangga, Surabaya \\ ${ }^{2}$ Departemen Manajemen Kesehatan Ikan dan Budidaya Perairan, Fakultas Perikanan dan Kelautan, Universitas \\ Airlangga, Surabaya \\ *arika.juniarsih@gmail.com
}

\begin{abstract}
Abstrak
Usaha budidaya ikan air tawar di Indonesia merupakan salah satu sektor usaha perikanan yang sangat potensial, salah satu usaha budidaya ikan air tawar yang mudah dan ekonomis dikembangkan adalah budidaya ikan mas (Cyprinus carpio, L.). Permasalahan yang sering dihadapi dalam usaha budidaya ikan adalah munculnya serangan penyakit yang dapat menyebabkan menurunnya tingkat produksi ikan. Penyakit pada ikan dapat disebabkan oleh agen infeksi seperti parasit, bakteri, jamur, dan virus, serta agen non infeksi seperti kualitas pakan yang buruk dan kondisi lingkungan yang tidak sesuai dengan kehidupan ikan. Parasit adalah organisme yang hidup pada tubuh organisme lain dan menimbulkan kerugian pada inangnya. Salah satu jenis parasit yang umum menginfestasi budidaya ikan mas (Cyprinus carpio, L.) adalah parasit Argulus, yang merupakan salah satu ektoparasit obligat dari kelas Branchiura. Parasit ini menginfestasi ikan pada bagian sirip, permukaan tubuh, dan insang. Faktor penting yang perlu diperhatikan dalam usaha budidaya ikan mas (Cyprinus carpio, L.) adalah penyediaan lingkungan yang sesuai dengan kebutuhan ikan, kolam merupakan tempat tinggal untuk ikan, sehingga proses pembuatan kolam harus diperhatikan. Dasar kolam dalam budidaya terdapat dua dasar kolam yaitu dasar kolam tanah dan beton. Dasar kolam tanah merupakan dasar kolam yang terbuat dari tanah, tanah yang baik digunakan adalah jenis tanah lempung dan tidak berporos, karena jenis tanah tersebut dapat menahan air dalam jumlah besar. Dasar kolam beton merupakan dasar kolam yang terbuat dari semen, keuntungan dari dasar kolam ini adalah tidak mudah terkikis oleh air.
\end{abstract}

Kata Kunci: Budidaya Ikan Air Tawar, Penyakit, Parasit, Ektoparasit, dan Lingkungan

\begin{abstract}
Freshwater fish farming in Indonesia is one of the business sectors with huge potential fisheries, One of the cultivation of freshwater fish easily and economically developed is the aquaculture of carp (Cyprinuscarpio, L.). Problems encountered in fish farming is the emergence of the disease that can lead to reduced levels of fish production. Diseases of the fish can be caused by infectious agents such as parasites, bacteria, fungi, and viruses, as well as non-infectious agent such as a poor feed quality and environmental conditions incompatible with the life of the fish. Parasites are organisms that live on the bodies of other organisms and cause harm to its host. One common type of parasite that infests the aquaculture of carp (Cyprinuscarpio, L.) is a parasite Argulus, which is one of the class Branchiura obligate ectoparasites. This parasite infests fish on the fins, body surface and gills. The important factor to consider in the aquaculture of carp (Cyprinuscarpio, L.) is the provision of a suitable environment to the needs of the fish, the pond is a live media for fish. Base of the pond in the aquaculture of which there are two basic pond baseland and concrete. Basic land pond is a pond base made of land, land that is well used is the type of clay and does not pivot, because the type of land can hold water in large quantities Basic concrete pond is the bottom of the pond is made of cement, the basic advantage of this pond is not easily eroded by water.
\end{abstract}

Keywords: Freshwater Farming, Disease, Parasites, Ectoparasite, and Environment

\section{PENDAHULUAN}

Usaha budidaya ikan air tawar di Indonesia merupakan salah satu sektor usaha perikanan yang sangat potensial, usaha budidaya ikan air tawar sendiri dapat memberikan peranan yang nyata dalam 
pembangunan perikanan khususnya dalam pemenuhan konsumsi ikan dalam negri. Salah satu usaha budidaya ikan air tawar yang mudah dan ekonomis dikembangkan adalah budidaya ikan mas (Cyprinus carpio, L.).

Permasalahan yang sering dihadapi dalam usaha budidaya ikan adalah munculnya serangan penyakit yang dapat menyebabkan menurunnya tingkat produksi ikan. Penyakit adalah hasil ketidakseimbangan antara inang, patogen, dan lingkungan. Penyakit pada ikan dapat disebabkan oleh agen infeksi seperti parasit, bakteri, jamur, dan virus, serta agen non infeksi seperti kualitas pakan yang buruk dan kondisi lingkungan yang tidak sesuai dengan kehidupan ikan (Sumiati dan Aryati, 2010).

Salah satu penyakit yang umumnya menginfestasi budidaya ikan mas (Cyprinus carpio, L.) adalah serangan dari parasit. Parasit adalah organisme yang hidup pada tubuh organisme lain dan menimbulkan kerugian pada inangnya. Kerugian yang dapat ditimbulkan dari infestasi Salah satu jenis parasit yang umum menginfestasi budidaya ikan mas (Cyprinus carpio, L.) adalah parasit Argulus, yang merupakan salah satu ektoparasit obligat dari kelas Branchiura. Parasit ini menginfestasi ikan pada bagian sirip, permukaan tubuh, dan insang. Ikan yang terinfestasi parasit Argulus akan mengalami kehilangan nafsu makan sehingga ikan akan terlihat kurus, pada bagian tubuh yang terinfestasi akan timbul bercak merah akibat dari infetsasi Argulus (Hogans, 1994).

Faktor penting yang perlu diperhatikan dalam usaha budidaya ikan mas (Cyprinus carpio, L.) adalah penyediaan lingkungan yang sesuai dengan kebutuhan ikan. Salah satunya adalah penyediaan lingkungan tempat tinggal yang sesuai dengan kebutuhan ikan, kolam merupakan tempat tinggal untuk ikan, sehingga proses pembuatan kolam harus diperhatikan. Syarat yang harus dipenuhi dalam proses pembuatan kolam adalah pemilihan lokasi kolam, dasar kolam, dan saluran pemasukan dan pembuangan air (Gusrina, 2008).

Dasar kolam dalam budidaya terdapat dua dasar kolam yaitu dasar kolam tanah dan beton. Dasar kolam tanah merupakan dasar kolam yang terbuat dari tanah, tanah yang baik digunakan adalah jenis tanah lempung dan tidak berporos, karena jenis tanah tersebut dapat menahan air dalam jumlah besar dan mampu menyediakan unsur hara bagi kebutuhan nutrisi ikan. Dasar kolam beton merupakan dasar kolam yang terbuat dari semen, keuntungan dari dasar kolam ini adalah tidak mudah terkikis oleh air (Mahasri, 2005).

Pemilihan dasar kolam sangat perlu diperhatikan hal ini dikarenakan Argulus akan melakukan kopulasi di atas inang kemudian melepaskan telurnya dan meletakannya pada permukaan yang keras dan benda-benda yang ada di perairan. Menurut Walker (2008) Argulus betina dewasa ketika lepas dari inang akan cenderung ke dasar perairan untuk mencari tempat oviposisi seperti batu, pipa PVC, tanaman air, kayu, dan dasar kolam. Argulus akan meletakkan telurnya secara berderet dan sejajar pada obyek oviposisi yang sesuai, telur Argulus dilapisi semacam lendir pada semua bagian telur sehingga telur yang satu dengan yang lain dapat melekat secara kuat pada obyek oviposisi. Parasit merupakan salah satu penyebab kerugian dalam usaha budidaya, karena permasalahan tersebut maka dilakukan penelitian mengenai prevalensi Argulus yang menginfestasi ikan mas (Cyprinus carpio, L.) pada dasar kolam tanah dan beton di Kecamatan Muntilan dan Mungkid, Kab. Magelang.

\section{METODOLOGI}

\section{Waktu dan Tempat}

Pengambilan sampel dilaksanakan di Kecamatan Muntilan dan Kecamatan Mungkid, Kabupaten Magelang, Jawa Tengah. Pengamatan parasit dilakukan di Laboratorium Pendidikan Fakultas Peri- 
kanan dan Kelautan Universitas Airlangga. Penelitian ini dilaksanakan pada bulan Februari-Maret 2016.

\section{Materi Penelitian}

Peralatan Penelitian

Peralatan yang digunakan dalam penelitian adalah termometer, DO meter, $\mathrm{pH}$ meter, amonia test kit, pinset, microtube, baskom, kantong plastik, petri dish, pipet tetes, object glass, cover glass, dan mikroskop binokuler.

Bahan Penelitian

Bahan yang digunakan dalam penelitian ini adalah benih ikan mas (Cyprinus carpio, L.) berukuran $\pm 5-15 \mathrm{~cm}$ dan alkohol gliserin 5\% sebagai bahan pengawet parasit Argulus.

\section{Metode Penelitian}

Penelitian ini menggunakan metode survey dalam pengambilan sampel, yaitu penelitian dengan mengambil sampel dari suatu populasi yang sedang diamati sekaligus diperoleh fakta-fakta dan gejalagejala yang ada, serta mencari keterangan secara faktual (Azwar, 1988). Penyajian data menggunakan metode deskriptif, yaitu membuat deskripsi mengenai situasi atau kejadian tertentu (Suryabrata, 1993). Deskripsi dalam penelitian adalah untuk mengetahui prevalensi Argulus yang menginfestasi ikan mas (Cyprinus carpio, L.) pada dasar kolam tanah dan beton di Kecamatan Muntilan dan Mungkid, Kab. Magelang.

\section{Prosedur Kerja \\ Pengambilan Sampel}

Menurut Barreiro danAlbandoz (2001) bahwa jumlah ikan sampel yang diambil sebesar $10 \%$ dari total populasi ikan pada tiap kolam yang dilakukan secara acak sehingga data yang diperoleh representatif mewakili populasi dan memberi peluang yang sama pada seluruh anggota populasi. Pengambilan sampel pada kolam dengan dasar tanah diambil dari satu kolam dengan ukuran kolam
$4 \times 3 \times 1 \mathrm{~m}^{3}$ dengan jumlah populasi 103 ekor, sehingga total jumlah sampel 10 ekor di Kecamatan Muntilan . Sampel ikan mas di Kecamatan Mungkid diambil dari dua kolam dengan masing-masing kolam berukuran $2 \times 2 \times 1 \quad \mathrm{~m}^{3}$ dan $4,5 \times 3 \times 1,5 \mathrm{~m}^{3}$ dengan jumlah populasi masing-masing kolam 96 ekor dan 98 ekor, total sampel yang diambil sebanyak 20 ekor. Pengambilan sampel pada kolam dengan dasar beton diambil dari satu kolam dengan ukuran kolam $5,6 \times 4 \times 1 \mathrm{~m}^{3}$ dengan jumlah populasi 94 ekor, sehingga total jumlah sampel 10 ekor di Kecamatan Muntilan. Sampel ikan mas di Kecamatan Mungkid diambil dari satu kolam dengan ukuran kolam $2 \times 1 \times 0,45 \mathrm{~m}^{3}$ dengan jumlah populasi 100 ekor, sehingga total jumlah sampel 10 ekor.

\section{Pemeriksaan Sampel}

Prosedur pemeriksaan sampel diawali dengan pengamatan untuk membedakan predileksi Argulus. Sampel disimpan dalam mikrotube dengan perendaman menggunakan alcohol gliserin 5\%. Selanjutnya pemeriksaan dilakukan secara natif untuk mengidentifikasi Argulus berdasarkan kunci dari Kabata (1984) dan Pilgrim (1967). Pemeriksaan dilakukan dengan menggunakan mikroskop binokuler.

\section{Pengamatan Predileksi}

Pengamatan predileksi Argulus pada ikan mas (Cyprinus carpio, L.) dilakukan secara langsung (makroskopis). Pengambilan sampel serta pengamatan predileksi dilihat langsung saat ikan berada di kolam budidaya untuk menghindari Argulus berpindah tempat saat transporttasi. Pengamatan predileksi Argulus pada permukaan tubuh dan sirip ikan yang meliputi sirip dorsal, pectoral, ventral, anal, dan caudal.

\section{Pengukuran Kualitas Air}

Pengukuran kualitas air yang dilakukan adalah suhu, DO, $\mathrm{pH}$, dan ammonia. Pengukuran kualitas air dilakukan di kolam tempat pengambilan sampel. 
Lokasi pengambilan sampel memungkinkan adanya perbedaan nilai kualitas air, karena terdapat perbedaan ukuran kolam, kepadatan kolam, serta dasar kolam yang digunakan. Semakin buruk keadaan kolam dan semakin buruk kondisi kualitas air pada perairan dapat menyebabkan semakin berkembangnya telur Argulus.

\section{Analisis Data}

Data hasil pemeriksaan infestasi Argulus pada ikan mas (Cyprinus carpio, L.) dianalisis secara deksriptif dan disajikan dalam bentuk gambar dan tabel. Analisis data Chi-square digunakan untuk melihat perbedaan jumlah ikan mas (Cyp- rinus carpio, L.) yang terinfestasi Argulus pada kolam dengan dasar tanah dan beton.

\section{HASIL DAN PEMBAHASAN \\ Infestasi Argulus Pada Ikan Mas (Cyprinus carpio, L.)}

Penelitian terhadap total ikan sebanyak 50 ekor yang diambil dari kolam dengan dasar tanah dan beton di Kecamatan Muntilan dan Mungkid, Kabupaten Magelang yang dilakukan secara sampling ditemukan parasit Argulus yang menginfestasi ikan mas (Cyprinus carpio, L.). Hasil perhitungan prevalensi ikan mas yang terinfestasi Argulus pada dasar kolam tanah dan beton dapat dilihat pada Tabel 1.

Tabel 1. Ikan mas yang terinfestasi Argulus pada dasar kolam tanah dan beton di Kecamatan Muntilan dan Mungkid

\begin{tabular}{lcccc}
\hline \multicolumn{1}{c}{ Sampel } & Dasar Tanah & Dasar Beton & $\begin{array}{c}\text { Nilai X }^{\mathbf{2}} \\
\text { Hitung }\end{array}$ & $\begin{array}{c}\text { Nilai X }^{\mathbf{2}} \\
\text { Tabel }\end{array}$ \\
\hline $\begin{array}{l}\text { Jumlah Total Ikan (ekor) } \\
\text { Jumlah Ikan yang }\end{array}$ & 30 & 20 & & \\
$\begin{array}{l}\text { Terinfestasi (ekor) } \\
\text { Prevalensi (\%) }\end{array}$ & 26,7 & 13 & & \\
$\begin{array}{l}\text { Kategori } \\
\text { (Williams and Williams, }\end{array}$ & Often & Frequently & & \\
1996) & & & 7,239 & \\
\hline
\end{tabular}

\section{Kualitas Air}

Infestasi Argulus pada budidaya ikan mas (Cyprinus carpio, L.) di Kecamatan Muntilan dan Mungkid, Kabupaten Magelang dipengaruhi oleh kondisi kualitas air yang digunakan sebagai media hidup, karena pada kualitas air yang buruk akan mempengaruhi infestasi parasit yang semakin tinggi. Data kisaran kualitas air dapat dilihat pada Tabel 2 .

Tabel 2. Kualitas air pada lokasi budidaya ikan mas (Cyprinus carpio, L.)

\begin{tabular}{|c|c|c|c|c|}
\hline \multirow{2}{*}{ Dasar Kolam } & \multicolumn{4}{|c|}{ Kualitas Air } \\
\hline & Suhu $\left({ }^{\circ} \mathbf{C}\right)$ & pH & DO & $\operatorname{Ammonia}(\mathrm{mg} / \mathrm{L})$ \\
\hline Tanah & 27,83 & 7,68 & 3,26 & 0,5 \\
\hline Beton & 27,25 & 7,43 & 3,5 & 0 \\
\hline
\end{tabular}

\section{Pembahasan}

Berdasarkan hasil pemeriksaan yang dilakukan terhadap 30 ekor sampel ikan mas (Cyprinus carpio, L.) yang dibudidayakan pada dasar kolam tanah ditemukan sebanyak delapan ekor ikan positif terinfestasi Argulus dan 22 ekor ikan negatif terinfestasi Argulus. Hasil perhitungan prevalensi ikan mas yang terinfestasi Argulus pada kolam dengan dasar tanah sebesar $26,7 \%$ dan termasuk dalam kategori Often, sedangkan hasil pemeriksaan yang dilakukan terhadap 20 ekor sampel ikan mas yang dibudidayakan 
pada dasar kolam beton sebanyak 13 ekor ikan positif terinfestasi Argulus dan tujuh ekor ikan negatif terinfestasi Argulus.

Hasil perhitungan prevalensi ikan mas yang terinfestasi Argulus pada kolam dengan dasar beton sebesar $65 \%$ dan termasuk dalam kategori Frequently. Tingginya nilai prevalensi ikan mas yang terinfestasi Argulus pada kolam budidaya dengan dasar beton dapat dipengaruhi karena dasar beton memiliki permukaan yang keras dan kokoh, sehingga dimungkinkan jumlah penempelan telur Argulus meningkat. Sedangkan rendahnya nilai prevalensi pada kolam dengan dasar tanah dapat dipenagruhi karena tanah yang digunakan untuk budidaya memiliki sifat yang lunak, sehingga penempelan telur Argulus dilakukan pada benda-benda sekitarnya (batu, pipa PVC saluran pemasukan dan pembuangan air, dinding kolam, tanaman air, dan kayu).

Hasil perhitungan analisis data $C h i$ square yaitu nilai $\mathrm{x}^{2}$ hitung sebesar 7,239 lebih besar dari nilai $\mathrm{x}^{2}$ tabel sebesar 3,84 , sehingga $\mathrm{H} 0$ ditolak dan $\mathrm{H} 1$ diterima maka kesimpulan yang didapat adalah terdapat perbedaan antara ikan mas (Cyprinus carpio, L.) yang terinfestasi Arguluspada kolam dengan dasar tanah dan beton. Adanya perbedaan ikan mas (Cyprinus carpio, L.) yang terinfestasi Argulus pada kolam dengan dasar tanah dan beton dikarenakan adanya obyek oviposisi yang sesuai dengan penempelan telur Argulus. Pada dasar tanah obyek oviposisi dapat dilakukan pada batu-batuan, tanaman air, pipa PVC, dan kayu, sedangkan pada kolam dengan dasar beton obyek oviposisidapat dilakukan pada dasar kolam karena dasar kolam beton terbuat dari semen dan memiliki tekstur permukaan yang keras dan kokoh.

Terdapatnya infestasi Argulus pada kegiatan budidaya ikan mas di kolam dasar tanah dan beton disebabkan oleh manajemen pemeliharaan ikan yang kurang baik dan tidak terkontrolnya kualitas air yang bergantung pada musim. Tingginya nilai prevalensi yang didapat pada masing- masing kolam budidaya dapat dipengaruhi dari kualitas pakan yang di berikan buruk sehingga dapat mempengaruhi pertumbuhan ikan, selain itu padat tebar yang terlalu tinggi dapat menyebabkan ikan stress sehingga memungkinkan ikan lebih mudah terserang parasit dan menyebabkan parasit berkembang dengan cepat. Padat penebaran yang tinggi dapat mengakibatkan terjadinya kompetisi terhadap ruang gerak, kebutuhan makanan dan oksigen.

Menurut Hogans (1994) parasit Argulus sering menyerang ikan budidaya pada bagian permukaan tubuh (kulit), sirip dorsal, sirip anal, sirip pectoral, sirip ventral, dan sirip caudal. Argulus akan menyerang ikan dnegan cara menempel dan menusuk pada tubuh inang dengan menggunakan stylet. Setelah Argulus menempelkan diri pada inang, parasit ini akan melepaskan zat anti koagulan yang berfungsi untuk mencegah pembekuan pada darah. Serangan parasit ini umumnya tidak menimbulkan kematian pada ikan yang terinfestasi, hal ini dikarenakan Argulus hanya menghisap darah inangnya menggunakan proboscis sehingga inang akan menjadi kurus. Infeksi dari parsit ini umumnya akan menyebabkan adanya luka pada permukaan tubuh, sirip geripis, warna tubuh terlihat pucat, lendir yang berlebihan, dan sisik lepas. Luka akibat serangan ektoparasit Argulus dapat menyebabkan infeksi sekunder yang disebabkan oleh bakteri, jamur, dan virus (Yildis and Kumantas, 2002).

Dasar kolam tanah merupakan dasar kolam yang terbuat dari tanah, dimana kondisi tanah yang baik untuk membuat kolam ikan adalah tanah yang mampu menyediakan berbagai unsur hara yang sangat diperlukan untuk pertumbuhan pakan alami, tanah dasar kolam harus mampu menahan air, dimana kemampuannya sangat dipengaruhi oleh tekstur tanah. Dasar kolam beton merupakan dasar kolam yang terbuat dari semen, memiliki sifat permukaan yang keras dan kokoh. Dalam hal ini dimungkinkan Argulus akan menempelkan telurnya pada batu yang ada 
pada dasar periaran (batu memiliki permukaan yang kasar dan datar), pipa PVC saluran pemasukan dan pengeluaran juga dapat dijadikan sebagai obyek penempelan telur Argulus, dimana Argulus dapat menempelkan telurnya secara berderet dan beraturan.

Dasar kolam beton memiliki tekstur yang keras dan kokoh sehingga hal ini dapat berpengaruh terhadap jumlah penempelan telur Argulus, dimana hal tersebut sesuai dengan pernyataan Walker (2008) bahwa Argulus betina akan meletakkan telurnya pada permukaan yang datar dan keras sehingga telur dapat melekat dengan kuat. Menurut Shimura and Egusa (1980) Argulus betina ketika lepas dari inang cenderung akan ke dasar perairan untuk mencari tempat oviposisi seperti batu, pipa PVC pada saluran pemasukan atau pengeluaran air, dinding kolam, dan dasar kolam. Telur Argulus dilapisi semacam lendir yang berfungsi sebagai pelindung. Lendir ini melapisi semua bagian dari cangkang telur dan menyatukan telur satu dengan yang lain membentuk deretan yang melekat kuat pada permukaan benda.

Berdasarkan hasil penelitian dari Kismiyati dkk (2010) menyatakan bahwa semakin lama penempelan telur terhadap suatu obyek oviposisi (batu, kayu, pipa PVC, tanaman air, dasar kolam) akan mempengaruhi jumlah penempelan telur terhadap obyek oviposisi yang sesuai dengan kopulasi Argulus. Permukaan dan tekstur obyek oviposisi akan mempengaruhi lama waktu penempelan telur sedangkan lama waktu penempelan telur berpengaruh terhadap jumlah telur yang menempel. Selain hal tersebut Argulus dalam menempelkan telurnya juga dapat dipengaruhi dari indera penglihatannya, dimana Argulus memiliki mata yang sensitif terhadap cahaya yang dapat membedakan terang dan gelap sehingga Argulus cenderung lebih menempel pada obyek yang berwarna gelap daripada obyek yang berwarna terang.
Pengukuran kualitas air pada penelitian meliputi suhu, $\mathrm{pH}, \mathrm{DO}$, dan ammonia. Hasil pengukuran suhu pada kolam dengan dasar tanah didapatkan nilai sebesar $27,83{ }^{\circ} \mathrm{C}$ dan pada kolam dengan dasar beton didapatkan nilai sebesar 27,25 ${ }^{\circ} \mathrm{C}$. Perbedaan suhu yang terjadi pada dasar kolam tanah dan beton dapat dipengaruhi dari musim, cuaca, ketinggian tempat, waktu pengukuran, dan kedalaman air.

Hasil pengukuran $\mathrm{pH}$ pada tiap-tiap dasar kolam budidaya didapatkan nilai sebesar 7,68 pada kolam dengan dasar tanah, sedangkan pada kolam dengan dasar beton didapatkan nilai sebesar 7,43. Oksigen terlarut pada kolam dengan dasar tanah adalah 3,26, sedangkan pada kolam dengan dasar beton 3,5. Kandungan oksigen terlarut pada tiap-tiap kolam berbeda hal ini dipengaruhi karena perbedaan suhu pada tiap-tiap kolam, tingginya oksigen terlarut dalam air maka suhu air semakin rendah, sebaliknya semakin tinggi suhu maka semakin rendah oksigen terlarutnya.

Hal ini dapat disebabkan karena meningkatnya suhu air akan menurunkan kemampuan air untuk mengikat oksigen, sehingga tingkat kejenuhan oksigen di dalam air juga akan menurun (Puspitaningrum dkk, 2012). Kadar amoniak pada tiap-tiap dasar kolam yaitu 0-0,5 mg/L. Kadar amoniak tersebut masih dalam batas optimal, menurut Boyd (1990) kadar amoniak yang masih dapat ditoleransi oleh organisme budidaya adalah kurang dari $1 \mathrm{mg} / \mathrm{L}$, apabila melebihi ambang batas tersebut maka dapat berbahaya bagi kehidupan ekosistem perairan.

\section{KESIMPULAN DAN SARAN Kesimpulan}

Prevalensi ikan mas (Cyprinus carpio, L.) yang terinfestasi Argulus di Kecamatan Muntilan dan Mungkid, Kabupaten Magelang dengan dasar kolam tanah lebih rendah $26,7 \%$ dibandingkan dengan dasar kolam beton sebesar $65 \%$ dan termasuk dalam kategori Often dan Frequently. 
Saran

Saran yang perlu dilakukan adalah adanya penelitian lebih lanjut untuk pengendalian ektoparasit Argulus sebagai upaya pengembangan usaha budidaya ikan mas (Cyprinus carpio, L.) di Indonesia.

\section{DAFTAR PUSTAKA}

Azwar, S. 1988. Metode Penelitian Pustaka Pelajar. Yogjakarta.

Badan Pusat Statistika Kabupaten Magelang. 2013. Hasil Sensus Pertanian 2013 Kabupaten Magelang. http://magelangkab.bps.go.id/Brs/vi ew/id/2. Tanggal 13 April 2016. 2 Hal.

Barreiro, P.I. and J.P. Albandoz. 2001. Management Mathematics for European Schools: Population and Smaple. Sampling Technique. The University of Serville.

Boyd, C.E. 1990. Water Quality in Pons Aquaculture. Alabama Agicultur Experimental Statiom. Auburn University. Alabama.

Gusrina. 2008. Budidaya Ikan Jilid 1. Direktorat Pembinaan Sekolah Menengah Kejuruan. Jakarta.

Hogans, B. 1994. Branchiuran Fish Louse Disease. Atlantic Reference Center. Huntsman Marine Science Center. Canada.

Kabata, Z. 1984. Parasite Disease of Fish Culture in The Tropics. Taylor and Francis. Londo. 263 p.

Kismiyati, N. M. Iskhaq, dan J. Triastuti. 2010. Obyek Kesukaan Untuk Penempelan Telur (Oviposisi) Ektoparasit Argulus japonicus. Jurnal Ilmiah Perikanan dan Kelautan, 2(2): 165-169.

Mahasri, G. 2005. Manajemen Kualitas Air. Fakultas Kedokteran Hewan. Universitas Airlangga. Surabaya. Hal 81.

Pilgrim, R. L. C. 1967. Argulus japonicas Thiele, 1900 (Crustacea : Branchiura)-a New Record from New Zealand. New Zealand
Journal of Marine and Freshwater Research 1:395-398.

Puspitaningrum, M., M. Izzati, dan S. Haryanti.2012. Produksi dan Konsumsi Oksigen Terlarut Oleh Beberapa Tumbuhan Air. Buletin Anatomi dan Fisiologi. Volume XX : 1.

Shimura, S and S. Egusa. 1980. Some Ecological Notes On The Egg Deposition Of Argulus coregoni Thorell (Crustacea, Branchiura). Fish Pathol 15: 43-47.

Sumiati, T., dan Y. Aryati. 2010. Penyakit Parasitik Pada Ikan Hias Air Tawar. Prosiding Forum Inovasi Teknologi Akuakultur. Balai Riset Perikanan Budidaya Air Tawar Bogor. Hal 963.

Suryabrata, S. 1993. Metode Penelitian. CV. Rajawali. Jakarta.

Yildiz, K. and A. Kumantas. 2002. Argulus foliaceus Infection in A Goldfish (Carassius auratus). Israel Journal of Veterinary Medicine, 57 (2): 118-120.

Walker, P. D. 2008. Argulus The Ecology of Fish Pest. Doctoral Thesis University Njimegen.

Williams, E.H. and L.B. Williams. 1996. Parasites of Offshore Big Gami Fishes of Puerio Rico and The Western Atlantic. Puerio Rico Departement of Natural and Environmental Resources. San Juan, PR. University of Puerio Rico. pp 383. 